$4^{\text {th }}$ International Meeting on Calcitonin Gene-Related Peptide (CGRP)

TheScientificWorld (2001) 1(S1), 42

ISSN 1532-2246; DOI 10.1100/tsw.2001.418

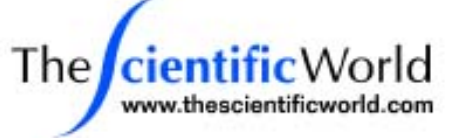

\title{
PHARMACOLOGY AND DESENSITISATION OF THE HUMAN RAMP3 AND RAT CALCITONIN RECEPTOR-LIKE RECEPTOR COMBINATION
}

\author{
D.L. Hay, T. Choksi, and D.M. Smith \\ Department of Metabolic Medicine, ICSM, London, W12 0NN, U.K.
}

Adrenomedullin (ADM) is a multifunctional regulatory peptide with its effects mediated by specific receptors. Here we examined the characteristics of the ratCRLR/humanRAMP3 combination stably expressed in HEK 293 cells with respect to binding of calcitonin family peptides and desensitisation of the ADM cAMP response following pre-exposure to ADM or other peptides. HEK 293 cells were stably transfected with rat CRLR and human RAMP3. Northern blot analysis of RNA extracted from these cells showed high expression of CRLR and RAMP3 and barely detectable levels of RAMPs 1 and $2 .{ }^{125}$ I-ratADM binding to RAMP3/CRLR was competed for by unlabelled rat ADM with an $\mathrm{IC}_{50}$ of $9 \mathrm{nM}$. CGRP and other calcitonin family members competed with ${ }^{125}$ I-ratADM more weakly with the following IC $_{50}$ values; $\alpha$-CGRP 168 nM, $\beta$-CGRP $69 \mathrm{nM}$, CGRP $_{8-37} 61 \mathrm{nM}$, cys(ACM2,7)CGRP $270 \mathrm{nM}$, human $\mathrm{ADM}_{22-52} 220 \mathrm{nM}$, rat amylin $117 \mathrm{nM}$, rat calcitonin $>1000 \mathrm{nM}$. Both ADM and CGRP caused elevation of cAMP with $\mathrm{ADM}$ being the most potent $\left(\mathrm{EC}_{50} 1.5 \pm 1.3 \mathrm{nM}\right.$ vs. $\left.18.0 \pm 1.1 \mathrm{nM}, \mathrm{n}=3\right)$. A 2-h preincubation of these cells with $100 \mathrm{nM} A D M$ resulted in a $93 \pm 1 \%(n=3)$ reduction in the subsequent cAMP response to $100 \mathrm{nM}$ ADM. A similar effect was seen with $\mathrm{ADM}_{13-50}$ but $\alpha-$ CGRP was less effective at this concentration. The desensitisation caused by ADM was not mimicked by $1 \mathrm{mM}$ dibutryl cAMP nor inhibited by pretreatment with the protein kinase A inhibitor H-89 (100 to $500 \mathrm{nM}$ ). Thus the ratCRLR/humanRAMP3 combination forms a receptor with higher affinity for ADM than CGRP which is potently desensitised by ADM. This desensitisation was not due to the activation of PKA. 

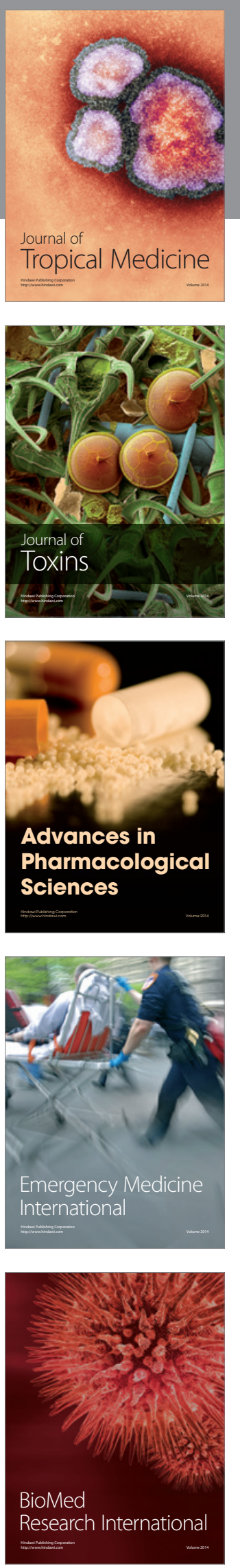
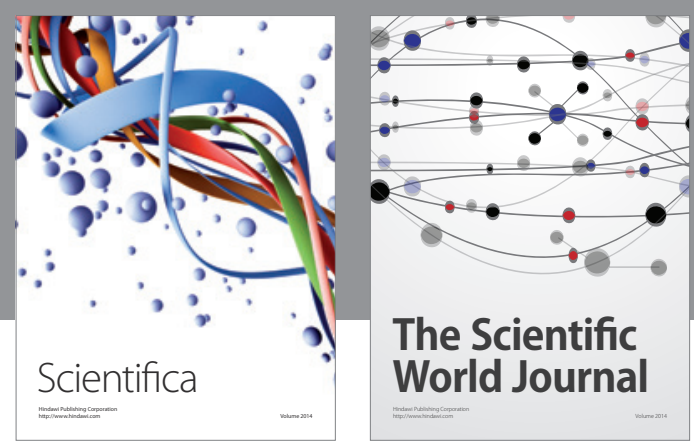

The Scientific World Journal
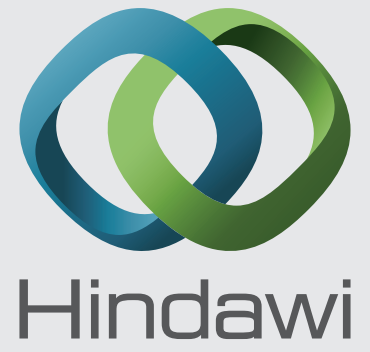

Submit your manuscripts at

http://www.hindawi.com
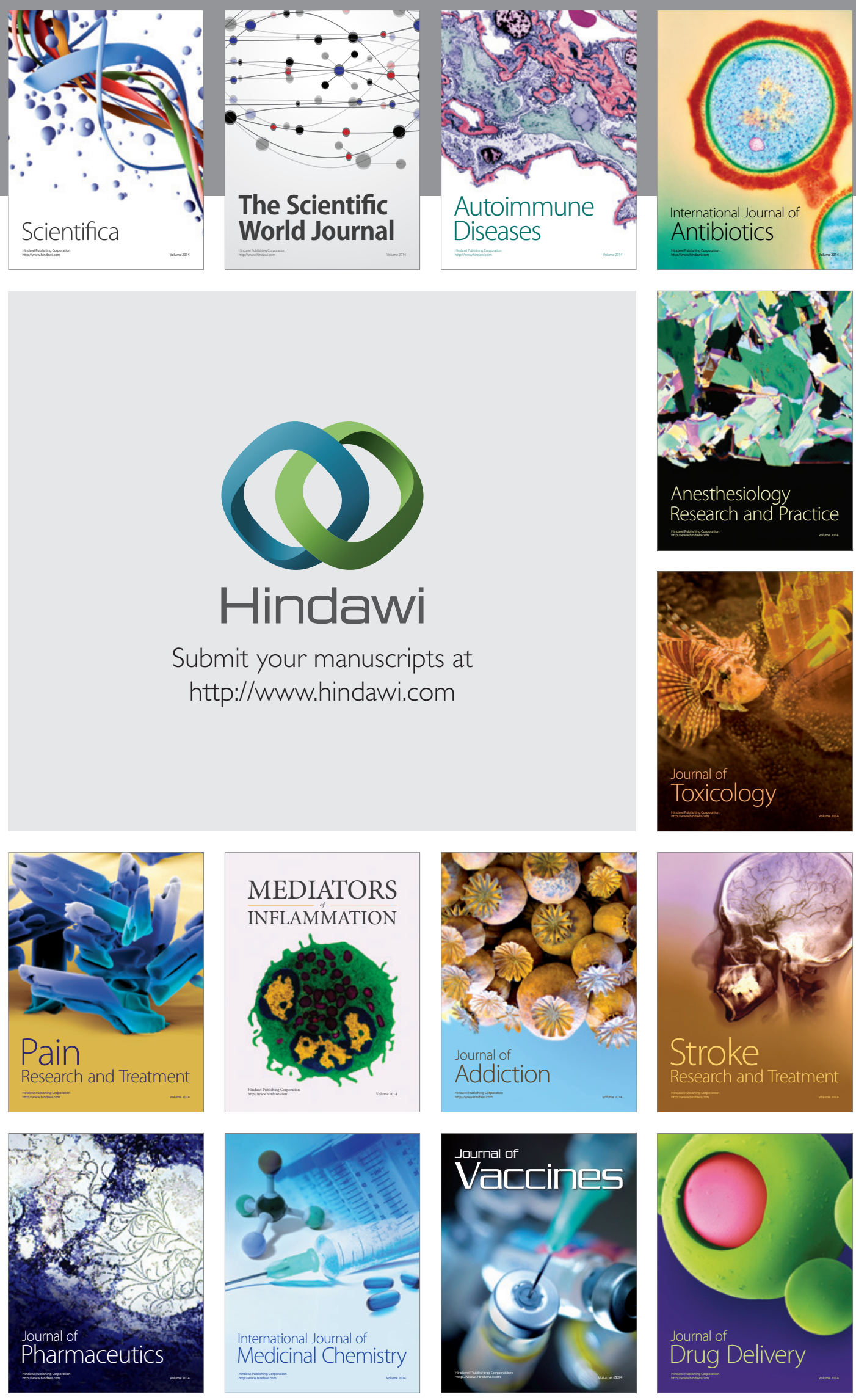